Correction

\title{
Correction: Liang, T.-C.; Peng, S.-H. Using Analytic Hierarchy Process to Examine the Success Factors of Autonomous Landscape Development in Rural Communities. Sustainability $2017,9,729$
}

\author{
Ta-Ching Liang ${ }^{1}$ (D) and Szu-Hsien Peng ${ }^{2, *(D)}$ \\ 1 Department of Leisure and Recreation, National Formosa University, Yunlin 632, Taiwan; taching@nfu.edu.tw \\ 2 Department of Spatial Design, Chienkuo Technology University, Changhua 500, Taiwan \\ * Correspondence: shpeng@cc.ctu.edu.tw; Tel.: +886-4-711-1111 (ext. 2256)
}

check for

updates

Citation: Liang, T.-C.; Peng, S.-H.

Correction: Liang, T.-C.; Peng, S.-H. Using Analytic Hierarchy Process to Examine the Success Factors of Autonomous Landscape Development in Rural Communities. Sustainability 2017, 9, 729. Sustainability 2022, 14, 2724. https:// doi.org/10.3390/su14052724

Received: 21 February 2022 Accepted: 23 February 2022 Published: 25 February 2022

Publisher's Note: MDPI stays neutral with regard to jurisdictional claims in published maps and institutional affiliations.

Copyright: (c) 2022 by the authors. Licensee MDPI, Basel, Switzerland. This article is an open access article distributed under the terms and conditions of the Creative Commons Attribution (CC BY) license (https:// creativecommons.org/licenses/by/ $4.0 /)$.
The authors would like to make the following corrections about the published paper [1] The changes are as follows:

Replacing the Acknowledgments:

Acknowledgments: We thank Ming-Yang Wu, a graduate of the Department of Leisure and Recreation at National Formosa University, who assisted in the investigation and analysis of the questionnaire task.

With

Acknowledgments: This is a translation/reprint of "Using AHP on the Successful Factors Examine of Autonomous Landscape Development in Rural Communities" originally published in Chinese by Journal of National Formosa University, 2016, volume 33, issue 3, pp. 71-87. This translation was prepared by Ta-Ching Liang and Szu-Hsien Peng. Permission was granted by Journal of National Formosa University, National Formosa University, and the authors. We thank Ming-Yang Wu, a graduate of the Department of Leisure and Recreation at National Formosa University, who assisted in the investigation and analysis of the questionnaire task.

The authors would like to apologize for any inconvenience caused to the readers and state that the scientific conclusions are unaffected. The original article has been updated.

\section{Reference}

1. Liang, T.-C.; Peng, S.-H. Using Analytic Hierarchy Process to Examine the Success Factors of Autonomous Landscape Development in Rural Communities. Sustainability 2017, 9, 729. [CrossRef] 